\title{
PREVALENCE OF EARLY CHILDHOOD CARIES IN CHILDREN OF THE KOSOVO POMORAVLJE AND POSSIBLE RISK FACTORS FOR ITS OCCURRENCE
}

\section{PREVALENCIJA KARIJESA RANOG DETINJSTVA U DECE KOSOVSKOG POMORAVLJA I MOGUĆI FAKTORI RIZIKA ZA NJEGOV NASTANAK}

\author{
Protić Ilić Milena (1), Tušek Ivan (2), Živković Milan (3), Vukićević Vladanka (3), Ilić Aleksandra (3)
}

(1) HEALTH CENTER GNJILANE, SERBIA, (2) FACULTY OF MEDICINE UNIVERSITY OF NOVI SAD, SERBIA, (3) FACULTY OF MEDICINE UNIVERSITY OF PRISTINA, DEPARTMENT FOR DENTISTRY, KOSOVSKA MITROVICA, SERBIA

Summary: Background/Aim. Early childhood caries (ECC) is an infectious multifactorial disease, which involves the presence of caries on any deciduous teeth in children up to the age of 71 months, and begins through a complex process involving the transmission of infectious bacteria, eating habits, and oral hygiene. The purpose of this paper was to examine the prevalence and possible risk factors for the emergence of caries in early childhood. Methods. The research was carried out as an analytical crosssectional study, including 239 children aged 13-71 months, of both genders living in rural areas of the Kosovo Pomoravlje region. All selected children from the sample were examined with standard dental diagnostic tools (dental mirrors, dental probe) under artificial lighting in a dental chair. Klein-Palmer's DMFT system (d-decayed, m-missing, f-filling) was used to identify caries. Data on social status, attitudes, habits, and behavior of the parents of the examined children are recorded in questionnaires specially designed for this study. Results. Prevalence of caries in the study sample was $56.5 \%$. The average number of diseased teeth per respondent for all children tested was 4.0. In analyzing the received data, the following seven possible ECC predictors with a significance level of $p<0.05$ were found to be of statistical relevance: the age of the mother $(p=0.004)$, visits to the dentist $(p=0.026)$ the reason for visiting the dentist $(p=0.038)$, use of a bottle in nursing $(p=0.001)$, child's age $(p<0.001)$, child's birth order $(p=$ $0.007)$, and the child's teeth brushing habits $(\mathrm{p}=0.003)$. Conclusion. The data obtained in the study indicated a high prevalence of deciduous teeth caries in the examined children, which indicates the need for intensive preventive efforts, both with children and the parents, as well as early diagnosis and treatment for early childhood caries.

Key words: Early childhood caries, children, deciduous teeth, prevalence, risk factors

Sažetak: Uvod. Karijes ranog detinjstva (KRD) je infektivno, multifaktorijalno oboljenje, koje podrazumeva prisustvo karijesa na bilo kom mlečnom zubu kod dece starosti do 71. meseca, a nastaje kompleksnim procesom, koji uključuje transmisiju infektivnih bakterija, navike u ishrani I oralnu higijenu. Cilj ovog rada je bio da se ispita prevalencija i mogući faktori rizika za pojavu karijesa u ranom detinjstvu. Metode. Istraživanje je izvedeno kao analitička studija preseka, a obuhvatilo je 239 deceu zrasta od 13-71. Meseca života, oba pola koja žive u ruralnoj sredini, na teritoriji Kosovskog Pomoravlja. Sva izabrana deca iz uzorka pregledana su standardnim stomatološkim dijagnostičkim sredstvima (stomatološko ogledalce, stomatološka sonda) pri veštačkom osvetljenju na stomatološkoj stolici. Za označavanje karijesa upotrebljen je Klajn-Palmerov (Klein-Palmer) sistem "kep". Podaci o socijalnom statusu, stavovima, navikama i ponašanju roditelja pregledane dece evidentirani su u anketne upitnike posebno dizajnirane za ovo istraživanje. Rezultati. Prevalencija karijesa u ispitivanom uzorku iznosila je 56.5\%. Prosečan broj obolelih zuba po jednom ispitaniku iznosio je 4,0. Analizirajući dobijene odgovore ustanovljeno je da kao mogući prediktori KRD, sa nivoom značajnosti od $p<0,05$, statistički značajno se izdvojilo 7 varijabli: starost majke $(\mathrm{p}=0.004)$, posete stomatologu $(\mathrm{p}=0.026)$ razlog posete stomatologu $(\mathrm{p}=0.038)$, upotreba bočice $(\mathrm{p}=0.001)$, uzrast deteta $(\mathrm{p}<0.001)$, dete po rođenju $(\mathrm{p}=0.007)$ i pranje zuba kod dece $(p=0.003)$. Zaključak. Dobijeni rezultati su pokazali visoku prevalenciju karijesa mlečnih zuba 
kod ispitivane dece, što ukazuje na potrebu intenzivnog preventivno-profilaktičkog rada, kako s decom, tako i sa roditeljima, kao i na ranu dijagnostiku i terapiju karijesa u ranom detinjstvu.

Ključne reči: Karijes ranog detinjstva, deca, mlečni zubi, prevalence, faktori rizika.

\section{Introduction}

Early Childhood Caries (ECC) is an infectious multifactorial disease, defined as the presence of one or more surfaces with a caries lesion (with or without cavitation), missing fillings or surfaces of teeth (due to caries), on any deciduous tooth among children up to 71 months [1,2].

Early childhood caries (nursing bottle caries, baby bottle tooth decay, night bottle mouth, and night bottle caries), as a specific form of deciduous tooth decay, is characterized by its early onset, atypical and specific localization, acute flow, rapid complication, generalization, and often severe consequences. Its incidence leads to changes in diet due to pain or lack of teeth, the appearance of dentoalveolar infections, the possibility of damage to the embryos of permanent teeth, diseases of the digestive tract, frequent occurrence of respiratory infections, and disorders in the general physical development of the child [3].

Of great importance is the fact that deciduous dentition caries are a good indicator of risk for developing caries in permanent dentition $[3,4,5]$, which is why modern protocols insist on implementing early prevention in pregnancy and first year of life [6].

According to relevant research, this is one of the most common chronic infectious diseases in childhood, which is very difficult to control due to its multifactorial etiology $[7,8]$.

In the contemporary understanding of the etiology of ECC, the primary focus is on the conditions that exist in the child's oral cavity at the earliest age, which is normally dominated by frequent lactation, feeding with a bottle, excessive intake of foods rich in sucrose, as well as the absence of adequate oral hygiene by parents or caregivers [9].Incorrect eating habits allow the selective development of aggressive acidogenic forms of streptococcus, primarily from the Streptococcus Mutans group $[10,11]$. Obviously, also of particular importance is the amount of cariogenic bacteria to which the child is exposed in their immediate environment (family) in the first 18 months, which is designated as the "gate of infection" [12].
Given this complex etiology, but also the lack of data from the earliest age, it is considered that any additional research contributes to solving the problem of caries in the youngest age [9].

The goal of our research was to determine the frequency of ECC in children living in the Kosovo Pomoravlje region and identify possible risk factors for the occurrence of this disease.

\section{Methods}

This study was approved by the Ethics Committee of the Faculty of Medicine University of Pristina, based in Kosovska Mitrovica (No. 091559). All clinical trials were performed by two dentists on the principles of good clinical practice. Kappa statistics were used to evaluate the reliability of the researchers. Kappa values evaluated after a review for the intraconsistency of the researchers amounted to 0.94 . The study was carried out in 2017/18, and included 239 children of both sexes, aged 13-71 months, living in rural areas of the Kosovo Pomoravlje region. Prior to the examination, the parents were given a written notice detailing the methodology and the purpose of the research, and requesting written consent for the participation of children in the study. The parent (guardian) who gave their consent to the participation of children in the examination was then interviewed before the child's dental examination. Data on social status, attitudes, habits and the behaviors of the examined children's parents are recorded in questionnaires specially designed for this study. Data on caries prevalence was recorded on a research card which was also designed for this study according to WHO recommendations and forms an integral part of the questionnaire. Examinations were conducted using a dental probe and a mirror under artificial lighting in a dental chair, in the presence of a parent. KleinPalmer's DMFT system was used to indicate caries.

In data evaluation, descriptive and inferential statistical data methods were used. The descriptive statistical parameters analyzed the prevalence of caries using the DMFT index (ddecayed, m-missing, f-filling), the caries tooth index, and the caries average index. As far as 
inferential methods, variance analysis, $\chi 2$-test $(\mathrm{p}$ $<0.05$ ) and logistic regression were used to separate the risk factors from observed outcome, i.e., caries of early childhood. Each of the investigated risk factors was analyzed in particular by univariate logistic regression, and factors that showed statistical significance were included in the multivariate logistic regression analysis that separated independent risk factors, that is, the predictors for the emergence of ECC. In order to analyze the difference in frequency and between groups, the chi-squared test and the Fisher test of the exact probability were employed. The multi-logical regression model included all predictors that had a statistical significance at the level of 0.05 . For the statistical analysis of the results, the software program SPSS Statistics 22 (SPSS Inc., Chicago, IL, USA) was used.

\section{Results}

The total sample was 239 children aged 13-71 months, of which 112 (46.86\%) were male and 127 (53.14\%) female.

The prevalence of caries in the sample was found to be $56.5 \%$. The average value of caries index of teeth was $29.1 \%$, and the average number of affected teeth per respondent was 4.0. Untreated cavities dominated (94.4\%) the DMFT, followed by extracted teeth (3.8\%) and a smaller percentage of sealed teeth $(1.8 \%)$.

The variables examined - the risk factors for the emergence of ECC are shown in the tables which follow (Tables 1 and 2), of which the variables related to the mothers of the examined children are shown in the first table (Table 1), while those in the second table (Table 2) relate to the child. Each variable is shown in relation to the incidence of ECC or lack thereof in a particular child.

As statistically significant factors for the emergence of caries of early childhood, and in relation to socio-demographic characteristics and habits in the examined mothers, the age of mothers (Chi-square test $=11.162, \mathrm{p}=0.004$ ), visits to the dentist during the pregnancy one or more times (Chi-square test $=4.943, \mathrm{p}=0.026$ ) and dental attendance during pregnancy due to teeth problems (Chi-square test $=4.319, \mathrm{p}$ $=0.038)$ (Table 1).

Table 1. Socio-demographic characteristics and habits of the examined mothers

\begin{tabular}{|c|c|c|c|}
\hline \multirow[t]{3}{*}{ Characteristics of the examined mothers } & \multicolumn{2}{|c|}{ ECC } & \multirow[t]{3}{*}{$\mathrm{p}$} \\
\hline & No & Yes & \\
\hline & $104(43.5)$ & $135(56.5)$ & \\
\hline Mother's age & $\mathrm{n}(\%)$ & $\mathrm{n}(\%)$ & \multirow{4}{*}{0.004} \\
\hline$<25$ years & $25(56.8)$ & $19(43.2)$ & \\
\hline 26-30 years & $55(48.7)$ & $58(51.3)$ & \\
\hline$>31$ years & $24(29.3)$ & $58(70.7)$ & \\
\hline \multicolumn{4}{|l|}{ Marital status } \\
\hline Married & $104(43.5)$ & $135(56.5)$ & l \\
\hline \multicolumn{4}{|l|}{ Education level } \\
\hline Elementary School & $2(20.0)$ & $8(80.0)$ & \multirow[t]{3}{*}{0.257} \\
\hline Secondary School & $66(43.1)$ & $87(56.9)$ & \\
\hline Technical school or University & $36(47.4)$ & $40(52.6)$ & \\
\hline \multicolumn{4}{|l|}{ Employment status } \\
\hline Employed full time & $20(40.8)$ & $29(59.2)$ & \multirow[t]{3}{*}{0.879} \\
\hline Unemployed or employed part time & $80(44.4)$ & $100(55.6)$ & \\
\hline No income & $4(40.0)$ & $6(60.0)$ & \\
\hline \multicolumn{4}{|l|}{ Cigarette usage } \\
\hline Yes, every day & $5(62.5)$ & $3(37.5)$ & \multirow[t]{3}{*}{0.540} \\
\hline Yes, sometimes & $8(44.4)$ & $10(55.6)$ & \\
\hline No & $91(42.7)$ & $122(57.3)$ & \\
\hline \multicolumn{4}{|l|}{ Alcohol consumption } \\
\hline Yes (a few times per week/month) & $1(33.3)$ & $2(66.7)$ & \multirow[t]{2}{*}{0.720} \\
\hline No & $103(43.6)$ & $133(56.4)$ & \\
\hline Visits to a dentist during pregnancy & & & \\
\hline
\end{tabular}




\begin{tabular}{|c|c|c|c|}
\hline Not once & $71(49.3)$ & $73(50.7)$ & \multirow[t]{2}{*}{0.026} \\
\hline Once or more times & $33(34.7)$ & $62(65.3)$ & \\
\hline \multicolumn{4}{|l|}{ Reason for visiting the dentist } \\
\hline Did not go or went for & $70(49.3)$ & $72(50.7)$ & \multirow[t]{3}{*}{0.038} \\
\hline regular checkup & $12(40.0)$ & $18(60.0)$ & \\
\hline Pain, tooth removal, filling, UZK* & $22(32.8)$ & $45(67.2)$ & \\
\hline \multicolumn{4}{|l|}{ Frequency of brushing } \\
\hline Did not brush teeth & $25(56.8)$ & $19(43.2)$ & \multirow[t]{3}{*}{0.501} \\
\hline Once per day & $55(48.7)$ & $58(51.3)$ & \\
\hline Twice or more per day & $24(29.3)$ & $58(70.7)$ & \\
\hline \multicolumn{4}{|l|}{ Time of tooth brushing } \\
\hline In the morning and evening & $2(20.0)$ & $8(80.0)$ & \multirow{3}{*}{0.959} \\
\hline Irregular rhythm & $66(43.1)$ & $87(56.9)$ & \\
\hline did not brush teeth & $36(47.4)$ & $40(52.6)$ & \\
\hline \multicolumn{4}{|l|}{ Length of tooth brushing } \\
\hline More than 2 minutes & $63(40.6)$ & $92(59.4)$ & \multirow[t]{2}{*}{0.224} \\
\hline Less than two minutes or not sure & $41(48.8)$ & $43(51.2)$ & \\
\hline \multicolumn{4}{|l|}{ Dentifrices } \\
\hline Brush, thread, paste & $103(44.0)$ & $131(56.0)$ & \multirow[t]{2}{*}{0.284} \\
\hline Nothing of the above & $1(20.0)$ & $4(80.0)$ & \\
\hline \multicolumn{4}{|l|}{ Fluoride prophylaxis } \\
\hline $\begin{array}{l}\text { Every day beginning with } 4 \text { th month of } \\
\text { pregnancy }\end{array}$ & $8(47.1)$ & $9(52.9)$ & \multirow[t]{2}{*}{0.760} \\
\hline Did not take every day or at all & $96(43.2)$ & $126(56.8)$ & \\
\hline
\end{tabular}

The following variables appeared as statistically significant factors in the emergence of early childhood caries in relation to the children's sex, age and hygienic/dietary habits: the age of children (Chi-square test $=53.471, \mathrm{p}<0.001$ ), birth order (Chi-square test $=9.917, \mathrm{p}=0.007$ ), use of bottle in feeding (Chi-square test = 13.394, $\mathrm{p}=0.001$ ), and the child's teeth brushing habits (Chi-square test $=11.712, \mathrm{p}=0.003$ ) (Table 2).

Table 2. Characteristics of children in relation to sex, age, and hygienic/dietary habits

\begin{tabular}{|c|c|c|c|}
\hline \multirow[t]{2}{*}{ Characteristics of children } & \multicolumn{2}{|c|}{ ECC } & \multirow[b]{2}{*}{$\mathrm{p}$} \\
\hline & $\begin{array}{c}\text { No } \\
\text { n (\%) }\end{array}$ & $\begin{array}{c}\text { Yes } \\
\text { n (\%) }\end{array}$ & \\
\hline \multicolumn{4}{|l|}{ Sex } \\
\hline Male & $54(42.5)$ & $73(57.5)$ & \multirow[t]{2}{*}{0.741} \\
\hline Female & $50(44.6)$ & $62(55.4)$ & \\
\hline \multicolumn{4}{|l|}{ Time of delivery } \\
\hline On time & $85(42.7)$ & $114(57.3)$ & \multirow{3}{*}{0.556} \\
\hline Before time & $9(40.9)$ & $13(59.1)$ & \\
\hline Transferred & $10(55.6)$ & $8(44.0)$ & \\
\hline \multicolumn{4}{|l|}{ APGAR score } \\
\hline Good $(10,9,8)$ & $97(42.4)$ & $132(57.6)$ & \multirow[t]{2}{*}{0.258} \\
\hline $\operatorname{Bad}(7,6)$ & $5(62.5)$ & $3(37.5)$ & \\
\hline \multicolumn{4}{|l|}{ Child's birth weight } \\
\hline Up to $2500 \mathrm{~g}$. & $6(40.0)$ & $9(60.0)$ & \multirow[t]{2}{*}{0.777} \\
\hline g. or more & $98(43.8)$ & $126(56.3)$ & \\
\hline Age & & & \\
\hline $1-3$ years & $68(69.4)$ & $30(30.6)$ & $<0.001^{*}$ \\
\hline
\end{tabular}




\begin{tabular}{|c|c|c|c|}
\hline 4-5 years & $33(33.3)$ & $66(66.7)$ & \\
\hline Over 5 years & $3(7.1)$ & $39(92.9)$ & \\
\hline Birth order & & & \\
\hline First & $34(61.8)$ & $21(38.2)$ & \multirow{3}{*}{$0.007^{*}$} \\
\hline Second & $44(39.3)$ & $68(60.7)$ & \\
\hline Third or later & $26(36.1)$ & $46(63.9)$ & \\
\hline \multicolumn{4}{|l|}{ Breast feeding } \\
\hline No, I do not know & $61(43.9)$ & $78(56.1)$ & \multirow[t]{3}{*}{0.923} \\
\hline Yes, up to 6 months & $21(41.2)$ & $30(58.8)$ & \\
\hline Yes, more than 6 months & $22(44.9)$ & $27(55.1)$ & \\
\hline \multicolumn{4}{|l|}{ Use of the bottle } \\
\hline $\begin{array}{llll}\text { Use of milk bottle during } \\
\text { sleeping }\end{array}$ & $46(59.7)$ & $31(40.3)$ & \multirow{3}{*}{$0.001^{*}$} \\
\hline Use of milk bottle overnight & $49(38.0)$ & $80(62.0)$ & \\
\hline $\begin{array}{l}\text { Use of a sweetened bottle liquid } \\
\text { during sleeping (juice, milk with } \\
\text { biscuit, tea) }\end{array}$ & $9(27.3)$ & $24(72.7)$ & \\
\hline \multicolumn{4}{|l|}{ Tooth washing with a child } \\
\hline $\begin{array}{l}\text { The parent teaches the child } \\
\text { occasionally }\end{array}$ & $43(43.4)$ & $56(56.6)$ & \multirow{3}{*}{$0.003^{*}$} \\
\hline $\begin{array}{l}\text { Parents brushing their teeth } \\
\text { once a day }\end{array}$ & $34(34.3)$ & $65(65.7)$ & \\
\hline $\begin{array}{l}\text { The parent brushes the child } \\
\text { twice a day }\end{array}$ & $27(65.9)$ & $14(34.1)$ & \\
\hline
\end{tabular}

\section{$\mathrm{p}<0.05$ statistical significance}

The multiple logistic regression model included all variables that had a statistically significant association with the onset of early childhood caries with a significance level of 0.05 . The model contains seven predictors listed in Table 3 , which are compared to 239 respondents. The whole model (with all predictors) was statistically significant (Chi-square test $=75.765$, $\mathrm{p}<0.001$ ). In a multiple logistic regression model, statistically significant predictors of early childhood caries are: Bottle feeding [giving a bottle with milk during the night $(\mathrm{B}=0.772$; $\mathrm{p}=$ 0.028); bottle feeding with sweetened fluid while putting the child to sleep (juice, milk with cookies, tea) $(B=1.107 ; p=0.047)$ compared to the use of a milk bottle during sleep as a reference category], the child's age [age 3-5 $(B=1.356 ; \mathrm{p}<0.001)$, older than $5(\mathrm{~B}=3.028$; $\mathrm{p}<0.001$ ) compared to age $1-3$ as a reference category].

Table 3. Multiple logistic regression with the occurrence of early childhood caries as a dependent variable

\begin{tabular}{|c|c|c|c|c|c|}
\hline \multirow{2}{*}{ Independent variables } & \multirow{2}{*}{ B } & \multirow{2}{*}{$\mathrm{p}$} & \multirow{2}{*}{$\begin{array}{c}\text { OR } \\
\text { (Odds } \\
\text { Ratio) }\end{array}$} & \multicolumn{2}{|c|}{$\begin{array}{c}95 \% \text { interval of } \\
\text { accuracy }\end{array}$} \\
\hline & & & & $\begin{array}{l}\text { Lower } \\
\text { bound }\end{array}$ & $\begin{array}{l}\text { Upper } \\
\text { bound }\end{array}$ \\
\hline \multicolumn{6}{|l|}{ Mother's age } \\
\hline$<25$ years & \multicolumn{5}{|c|}{ Reference category } \\
\hline $26-30$ years & -0.218 & 0.620 & 0.804 & 0.340 & 1.902 \\
\hline$>31$ years & 0.230 & 0.644 & 1.259 & 0.474 & 3.347 \\
\hline \multicolumn{6}{|l|}{ Age } \\
\hline $1-3$ years & \multicolumn{5}{|c|}{ Reference category } \\
\hline $4-5$ years & 1.356 & $<0.001$ & 3.883 & 1.996 & 7.550 \\
\hline Over 5 years & 3.027 & $<0.001$ & 20.626 & 5.596 & 75.991 \\
\hline \multicolumn{6}{|l|}{ Birth order } \\
\hline First & \multicolumn{5}{|c|}{ Reference category } \\
\hline Second & 0.439 & 0.296 & 1.552 & 0.681 & 3.534 \\
\hline
\end{tabular}




\begin{tabular}{|c|c|c|c|c|c|}
\hline Third or later & -0.074 & 0.882 & 0.929 & 0.352 & 2.451 \\
\hline \multicolumn{6}{|l|}{ Visits to a dentist during pregnancy } \\
\hline Not once & \multicolumn{5}{|c|}{ Reference category } \\
\hline Once or more times & 0.628 & 0.598 & 1.875 & 0.181 & 19.406 \\
\hline \multicolumn{6}{|l|}{ Reason for visiting the dentist } \\
\hline Did not go or went for & \multicolumn{5}{|c|}{ Reference category } \\
\hline regular checkup & -0.337 & 0.770 & 0.714 & 0.075 & 6.798 \\
\hline Pain, tooth removal, filling, UZK* & -0.511 & 0.682 & 0.600 & 0.052 & 6.927 \\
\hline \multicolumn{6}{|l|}{ Use of the bottle } \\
\hline Use of milk bottle during sleeping & \multicolumn{5}{|c|}{ Reference category } \\
\hline Use of milk bottle overnight & 0.772 & 0.028 & 2.164 & 1.089 & 4.299 \\
\hline $\begin{array}{l}\text { Use of a sweetened bottle liquid during } \\
\text { sleeping (juice, milk with biscuit, tea) }\end{array}$ & 1.107 & 0.047 & 3.026 & 1.014 & 9.032 \\
\hline Tooth washing with a child & & & & & \\
\hline The parent teaches the child occasionally & \multicolumn{5}{|c|}{ Reference category } \\
\hline Parents brushing their teeth once a day & 0.158 & 0.649 & 1.172 & 0.593 & 2.316 \\
\hline The parent brushes the child twice a day & -0.765 & 0.094 & 0.465 & 0.190 & 1.138 \\
\hline
\end{tabular}

*UZK - removal of dental calculus

The strongest predictor (risk factor) for caries in early childhood is the child's age variable, and the age of children older than 5 years, whose risk factor is OR (Odds Ratio) $=20.626$. This shows that children older than 5 years have more than 20 times the risk of developing caries in early childhood, compared to the controls of all other factors in the model. Children aged 3-5 years have almost 4 times more risk of developing caries in early childhood.

Also, giving the child a bottle with a sweetened liquid while putting it to sleep increases the risk of caries by three, that the child will have caries in early childhood, OR $=3.026$, while this risk is somewhat smaller, OR $=2.164$ if the child is given a bottle of milk overnight.

\section{Discussion}

Early Childhood Caries (ECC) is a serious public health problem in both developed and developing countries around the world due to a high degree of prevalence. Prevalence is significantly lower in developed European countries and in the US, if socially vulnerable groups, immigrants, and individual ethnic communities are excluded from statistics $[13,14,15,16]$.

Unlike developed countries, the ECC problem in developing countries, and in particular in our country, it is even more important, because a large percentage of the infected teeth remain untreated $[16,17,18]$.

The prevalence of early childhood caries in this study is $56.5 \%$, with all subjects aged $13-71$ months. This value can be classified as a high incidence of the disease compared to the prevalence of ECC in pre-school children in Serbia's South Backa District [17], in children up to 24 months in Banja Luka [20], and three-year old's in Bulgaria [21].

As is an already recognized fact concerning the occurrence of ECC, there are large number of factors acting together which result in ECC, and as far as the possible ECC predictors in our study, with a significance level of $p<0.05$, we identify the following seven statistically significant variable factors: the age of the mother ( $p=0.004)$, the visits to a dentist during pregnancy $(p=0.026)$, the reason for visiting the dentist $(\mathrm{p}=0.038)$, the bottle use in feeding $(\mathrm{p}=$ $0.001)$, the age of the child ( $p<0.001)$, the child's birth order ( $p=0.007)$, and the child's teeth brushing habits $(\mathrm{p}=0.003)$. Our data shows that, the older mothers were, the higher the incidence of ECC, as confirmed by the fact that $70.7 \%$ of children with mothers over 30 years of age had early childhood caries. Information in foreign literature speaks of a greater prevalence of ECC in children whose mothers were younger [22, 23], while in Serbian authors [24], we find that children of younger mothers had more severe forms of early childhood caries. The fact that a higher prevalence of ECC in younger mothers can be explained by lower education levels and health information available to those mothers. However, the data which show children having higher instances of ECC with older mothers can be explained due to a series of socio-political 
circumstances, due to which at that time even basic health education was lacking.

Our study showed that children with more oral health problems (more frequent visit to the dentist, treatment, or tooth extractions) had a higher risk for the emergence of early childhood caries. This is explained by the greater probability of transmission of the Streptococcus mutans group of bacteria from mother to child, which is known in literature as "vertical transmission." A number of studies [25, 26] suggest a direct correlation between the mother's oral health and the prevalence of ECC in her children.

Eating habits are essential for the development of a cariogenic dental biofilm and the enhanced acid production. The most important habits that have a proven connection with the development of ECC are the improper use of a bottle with cariogenic substances such as milk, juices, sweetened tea or water, and especially night feeding, is confirmed in literature [17] and in our research. This finding point to the need for education of parents about the harmfulness of such habits, which were significantly related to the emergence of early childhood caries.

Obradovic's study in Banja Luka showed that at the age of two, almost $34 \%$ of children have carious lesions [27] and at the age of three, $48 \%$ of children, but also a high prevalence in older ages with deciduous dentition, such that at the age of six years only $5 \%$ of children without ECC and a caries index average of 8.3 [18].

Our research also shows that as the child grows up, the percentage of children with ECC increases, and this can be explained by teeth having been exposed to risk factors for a longer period of time.

As far as the variable of the "Child's birth order", our research showed that the third and every subsequently-born child had statistically significantly more caries, which is confirmed by numerous studies around the world and in Serbia $[28,29]$.

An explanation for this claim is the "easier" transmission of Streptococcus mutans bacteria among children in a collective environment, as well as between children and other family

REFERENCES:

1. Drury TF, Horowitz AM, Ismail AI, Maertens MP, Rozier RG5 Selwitz RH. Diagnosing and reporting early childhood caries for research purposes. J Public Health Dent. 1999; 59:192-197 members, which is described in literature as "horizontal transmission" [25].

Interestingly, Corrêa-Faria [30] suggests that in families with more children, the possibility of parental control over oral and hygienic habits is lessened, and thus the prevalence of ECC in their children is higher.

That a preschool child is unable to independently and properly maintain oral hygiene without supervision and help from their parents is indicated by a higher prevalence of ECC in this age group in our research, which is also confirmed by other similar studies [31,32]. Our data indicates, as do other authors [33], that children whose parents brushed their teeth twice a day had significantly less caries than children who wash their teeth only once a day or occasionally.

This necessitates the need for the promotion of oral health as well as the health education of parents, and therefore of their children. Considering the fact that Kosovo Pomoravlje is the region with poor knowledge of the parents about preventive dental treatments [34], poorer oral health of children is expected [35].The high prevalence of ECC in the region of Kosovo Pomoravlje indicates that this is a serious health problem that must be dealt with in a planned, synchronized and continuous manner through systematic prevention and timely and adequate treatment of ECC.

\section{Conclusion}

Our data shows that a mother's oral health is an extremely significant factor in whether or not her children will develop ECC. Thus, it is necessary to work on providing better health information and parents education, especially mothers, in how to maintain oral health, as well as on changing habits, attitudes and behaviors so they would later lead to the improvement of oral health in their children. In solving the problem, it is necessary to include all segments of society and work primarily on the diagnosis and elimination of risk factors for the development of ECC, as well as the necessary animation of both the user and providers of dental health services.

2. American Academy on Pediatric Dentistry; American Academy of Pediatrics. Policy on Early Childhood Caries (ECC): Classifications, Consequences, and Preventive Strategies. Pediatr Dent. 2008-2009;30:4043 
3. Clementino M, Gomes M, Pinto-Sarmento T, Martins C, Granville-Garcia A, Paiva S. Perceived Impact of Dental Pain on the Quality of Life of Preschool Children and Their Families. PLOS ONE. 2015;10(6):e0130602.

4. Skeie MS, Raadal M, Strand GV, Espelid I, Therelationship between caries in the primary at 5 years of age and permanent dentition at 10 yearsof age- a longitudinal study, Int J Paediatr Dent 2006; 16:152-60

5. Anita Alm. Dental Caries and Caries-RelatedFactors in Children and Teenagers, University ofGothenburg, 2008, ISSN 0348-6672

6. Ng MW, Chase I. Early childhood caries: risk-based disease prevention and management. Dent Clin North Am. 2013;57:1-16

7. Harris R, Nicoll AD, Adair PM, Pine CM. Risk factors for dental caries in young children: a systematic review of the literature. Community Dent Health. 2004; 21(1):71-85[PMID: 15072476]

8. Leong PM, Gussy MG, Barrow SY, de Silva-Sanigorski A, Waters E. A systematic review of risk factors during first year of life for early childhood caries. Int J Paediatr Dent. 2013; 23(4):235-50 [DOI: 10.1111/j.1365-263X.2012.01260.x] [PMID: 22925469]

9. Nishimura M, Oda T, Kariya N, Matsumura S, Shimono T. Using a caries activity test to predict caries risk in early childhood. J Am Dent Assoc 2008; 139:63-71 PMID: 18167387

10. Guido J, Martinez Mier E, Soto A, Eggertsson H, Sanders B, Jones J et al. Caries prevalence and its association with brushing habits, water availability, and the intake of sugared beverages. International Journal of Paediatric Dentistry. 2011;21(6):432-440

11. Adair SM. Evidence-based Use of Fluoride in Contemporary Pediatric Dental Practice. PediatrDent 2006; 28(2):133-42

12. Feldens CA, Giugliani ER, Vigo Á, Vítolo MR. Early feeding practices and severe early childhood caries in four-year-old children from southern Brazil: a birth cohort study. Caries Res. 2010; 44:445-52. doi: 10.1159/000319898 PMID: 20838043

13. Leong PM, Gussy MG, Barrow SUY et al. A systematic reviue during first year of life for early childchood caries, International Jurnal of Pediatric dentistry, 2013, 23:235-250

14. Dülgergil C, Dalli M, Hamidi M, Colak H. Early childhood caries update: A review of causes, diagnoses, and treatments. Journal of Natural Science, Biology and Medicine. 2013;4(1):29

15. Kawashita Y, Kitamura M, Saito T. Early Childhood Caries. International Journal of Dentistry. 2011;2011:1-7

16. Day BA et al: Prevalence and Measurement of Dental Caries in Young Children, Pediatric dentistry, 2015, 37:200-16

17. Obradović M, Dolić O, Vojinović J, Sukara S. Association between feeding habits and severe - early childhood caries in children up to 24 month old, Serbian Dental Journal,2016, 63(3): 117-124

18. Tušek I, Carević M, Tušek J. Influence of social environment on caries prevalence in early childhood:SrpArhCelokLek. 2011;139(1-2):18-24 (Serbian)

19. Obradovic M. Oral health of children up to 6 years of age in Center for pre-school education in the city of Banja Luka. Master Thesis. Banja Luka: Faculty of Medicine Banja Luka, Bosnia and Herzegovina. 2010.
20. Obradović M, Dolić O, Vojinović J, Sukara S. Association between feeding habits and severe - early childhood caries in children up to 24 month old, Serbian Dental Journal, 2016, 63(3): 117-124

21. Markova N. Earlychildhoodcaries:cariesinfantiane. Dissertation. Sofia: UniversityofSofia; 2003.

22. Warren JJ, Blanchette D, Dawson DV, Marshall TA, Phipps KR, Starr D, Drake DR.Factors associated with dental caries in a group of American Indian children at age 36 months.Community Dent Oral Epidemiol. 2016;44(2):154-61

23. Niji R, Arita K, Abe Y, Lucas ME, Nishino M, Mitome M. Maternal age at birth and other risk factors in early childhood caries.Pediatr Dent.2010 ;32(7):493-8

24. Tušek I,Carević M,Tušek J. Impact of social environment and ethnic affiliation on the development of caries in early childhood. Acta StomatologicaNaissi.2012;28(1):26-28

25. Lynch DJ, Villhauer AL, Warren JJ, Marshall TA, Dawson DV, Blanchette DR, Phipps KR, Starr DE, Drake DR. Genotypic characterization of initial acquisition of Streptococcus mutans in American Indian children. J Oral Microbiol. 2015;7:27182

26. Retnakumari N, Cyriac G. Childhood caries as influenced by maternal and child characteristics in pre-school children of Kerala:an epidemiological study. Contemp Clin Dent. 2012;3(1):2-8

27. Obradović M. The prevalence of early childhood caries and the effects of dental varnishes on initial caries lesions. Dissertation. Banja Luka: Faculty of Medicine, 2015

28. American Academy of Pediatrics. Oral health risk assessment timing and establishment of the dental home. Pediatrics 2003;111(5):1113-6

29. Tušek I. Impact of social environment and ethnic affiliation on the development of caries in early childhood. Dissertation. Belgrade: Faculty of Medicine University of Belgrade; 2009. (Serbian)

30. Corrêa-Faria P et al.Factors associated with the development of early childhood caries among Brazilian preschoolers. Braz Oral Res, 2013;27(4):35662

31. Policy on Early Childhood Caries (ECC): Classifications, Consequences, and Preventive Strategies. Reference manual. 2016; 37(6): 15-16

32. Tiberia MJ, Milnes AR, Feigal RJ, Morley KR, Richardson DS, Croft WG, et al. Risk factors for early childhood caries in Canadian preschool children seeking care. Pediatr Dent. 2007;29(3):201-8

33. Cvetković A, Vulović M, Ivanović M,Correlation between dental health status and environmental factors: nutrition, oral hygiene and saliva in childrenda, Serbian Dental J.2006;53(4):217-228

34. Mladenović R, Cvetković A, Martinović B, Milojković Z, Arsić Z, Đorđević F. Awareness, habits and behavior sassociated with the oral health of children in elementary schools on Kosovo and Metohia. Praxis medica 2015;44(2):1-5

35. Martinović, B., Cvetković, A., Milojković, Z., StošovićKalezić, I., Mladenović, R., Stevanović, M. The incidence of dental caries and gingivitis in school-aged children. Praxis medica, 2016: 45(2), 33-37. 